\title{
The application of personality traits model on the freight forwarding service industry
}

Kuo-Chung Shang

Department of Transportation Technology,

National Taiwan Ocean University, Keelung, Taiwan

Ching-Cheng Chao

Department of Shipping and Transportation Management, National Kaohsiung Marine University, Kaohsiung, Taiwan, and

Taih-Cherng Lirn

Department of Shipping and Transportation Management, National Taiwan Ocean University, Keelung, Taiwan

\begin{abstract}
Purpose - The purpose of this study aims to investigate the relationship between employees' personality traits and their job performances (including task performance and contextual performance) of Taiwanese freight forwarders by using responses from a NEO Personality Inventory-Revised Form (NEO-PI-R) questionnaire survey.

Design/methodology/approach - One of the most popular personality trait model is the five-factor model (FFM), which includes the big five domains, namely, openness, conscientiousness, extraversion, agreeableness and neuroticism (OCEAN). Each of these five domains includes six facets. Previous researchers have used OCEAN factors to describe the relationship between human personality and job performance. NEO Personality Inventory is a professional psychological assessment instrument published by psychological assessment resources. Multivariate analysis technique and regression technique are used to analyze surveyees' responses.

Findings - Research results reveal the following four issues. The seniority of employees in a company has a positive relationship with their conscientiousness. Employees with higher score on the facets of the neuroticism domain have a negative correlation with their task performance and contextual performance. The relationship between employees' openness to experience and job performance (both task performance and contextual performance) is not significant. Employees' seniority has a positive correlation with both their task performance and contextual performance. In a nutshell, freight forwarding industry in Taiwan can use the facets in the neuroticism domain to screen and recruit appropriate job applicants. In addition, retaining senior employees could increase a forwarder's task performance and contextual performance by their high degree of conscientiousness.

Originality/value - FFM model is a psychological theory dealing with the personality traits and human behavior. Freight forwarding is a labor-intensive business and is one of the most important

(C) Pacific Star Group Education Foundation

Authors are much obliged to two anonymous reviewers' constructive comments which greatly improve the quality of this paper. The authors would like to express their sincere thanks for the help received from Mr Kuo-Dung Chao during the questionnaire surveys. The research is financially supported by Grant NSC-101-2410-H-019-017 from the Taiwan's National Science Council.
\end{abstract}

Application of personality traits model 
MABR 1,3

sectors in the logistics industry. According the authors' knowledge, the application of FFM on the logistics industry is simply not existed.

Keywords Job performance, Five factor model FFM, Freight forwarding

Paper type Research paper

\section{Introduction}

Logistics industries play a critical role in world economy and forwarding industry as an important component of logistics industry, and it has direct effect on logistics industry. Freight forwarding is a labor-intensive industry. It is estimated that there are more than 800 freight forwarding companies in Taiwan. Among them, all of the ocean freight forwarders have employed over ten thousand staffs in Taiwan. The quality and personal trait of their employees might influence the performance of a freight forwarding company (Appendix 1).

It is reported by a senior executive in the industry that the annual employee turnover rate in the forwarding industry in the Great Chinese region might be as high as 27 per cent (Appendix 2). One professional human resource training company estimates the average training cost of a new employee is approximately US\$3,500 (Muller, 2011). If a new employee leaves and has to be replaced, such cost will be around US $\$ 4,700$ (Investtopedia, 2015). Another report by PR Newswire (2015) indicates that a company's employee turnover rate is a costly part of doing business. The employee's replacement expenses include the cost of advertising, headhunting fees, human resource costs, loss of productivity, new hire training and customer retention which might add up to anywhere from 30 to 200 per cent of a single employee's annual salary. High employee turnover rate is one of the employers' major hidden costs if they could not select the right employees during the interview processes. In addition, customer satisfaction is influenced by employee behaviors. You can never overemphasize the importance of including "personality" factors as part of the recruitment and selection processes (Stone and Ineson, 1997 cited in Aksu, 2008).

Five-factor model (FFM) model is a psychological theory dealing with personality traits and human behaviors (Filip et al., 2001). Freight forwarding is a labor-intensive business and is one of the most important sectors in the logistics industry. According to the authors' knowledge, the application of FFM in logistics industry is simply not existing.

\section{Literatures reviews on the five-factor model and job performance}

Traits, the primary unit of personality description, are relatively enduring and people may have very different traits. Personality inventories are questionnaires to measure the scores on a number of traits or characteristics. The NEO Personality Inventory, Revised (NEOPI-R) is the best-known and most empirically supported measure of the five factors. There are many models to measure the personality traits to select the appropriate employees in a broad spectrum of industries. Searching through the Science Direct database, it is found there are 43,421 literatures discussing the relationship of personality traits and the FFM, and 8,614 articles discussing the relationship between personality trait and job performance. FFM is one of the most popular personality measurement models (Filip et al., 2001). The FFM is investigating the five major personalities of openness, conscientiousness, extraversion, agreeableness and neuroticism (OCEAN). Openness is characterized by terms including original, ideas and imaginative. Conscientiousness is about the self-control, perseverance, 
achievement-striving and ambition. Extraversion is defined as the sociability, affection, friendliness and talkativeness. Agreeableness is perceived as trusting, straightforwardness, sympathetic and cooperative. Neuroticism is perceived as worry, insecurity and self-consciousness (Costa and McCrae, 1992; White, 2003).

There are critics on the FFM. Ashton (1998) discusses the relationship between employee personality and job performance and concludes the responsibility and risk-taking scales of the Jackson Personality Inventory could have higher validities than the Big Five dimensions with respect to job performance. Parker et al. (1993) indicate that the theoretical parameters of the five-factor personality model were assessed by subjecting the 30 subscales that comprise this scale to confirmatory factor analysis (CFA). Results from the CFA indicated a poor fit between the obtained factor structure and the hypothesized dimensions corresponding to the FFM. Dudley et al. (2006) examined the personality-performance relationship, and they compared the predictive power between general personality traits of the FFM and the narrow traits. They conclude their research results by suggesting that there are benefits in considering the narrow traits of conscientiousness in the prediction of performance. Bowler et al. (2009) assessed whether individuals with higher or lower levels of cognitive complexity have personalities which comprise a greater or lesser number of factors than the five in the FFM model, and they found individuals with lower levels of cognitive complexity have personalities best described by a three-factor model, whereas individuals with higher levels of cognitive complexity have personalities which can be best described by a seven-factor model. And they argued about whether the appropriateness of applying universally the FFM to individuals of differing levels of cognitive complexity should be discussed.

However, abundant literatures support the application of FFM on various occasions. Ones and Viswesvaran's (1996) research concluded that "broader and richer personality traits predictors, including FFM, will have higher predictive validity than narrower traits". Hurtz and Donovan (2000) indicate many previous studies and analyses that were not derived from actual FFM measures. They use the meta-analysis technique to estimate the relationship between the criterion-related validity of FFM and job performance and contextual performance. They indicate there are complex relations among the Big 5 and performance. Day and Silverman (1989) also study the relationship between specific personality variables and job performance of accountants. Their research finding indicates three personality scales (orientation towards work, degree of ascendancy and degree and quality of interpersonal orientation) are significantly related to important aspects of job performance. Blickle et al. (2009) reviewed the Hogan's (1991) socioanalytic perspective of performance prediction and investigated whether interactions of the FFM constructs of agreeableness and conscientiousness with political skill predict job performance. They found conscientiousness has interaction with political skill, and it does also significantly predict job performance. Blickle et al. (2010) investigated a sample of 112 car salespersons whether interactions of the FFM constructs of extraversion and openness to experience with political skill predict sales performance. They suggested that for individuals possessing great political skill, higher levels of extraversion of them were associated with higher levels of sales. For individuals possessing low political skill, higher levels of extraversion were associated with lower levels of sales.
Application of personality traits model

233 
MABR 1,3
Furnham and Fudge (2008) reviewed the previous FFM or personality traits literatures which suggested individuals with high Conscientiousness and Extraversion, as well as low Neuroticism, perform better in sales occupations. They test this argument by surveying 66 sales consultants from a sports organization, and these sales consultants are asked to complete the NEO-FFI form, and it was found that scores correlated with their sales performance. Conscientiousness and Openness has a positive relationship with sales, and agreeableness has a negative relationship with sales. However, the statistic relationship between sales performance and personality of Extraversion and Neuroticism is not significantly supported. Penney et al. (2011) review the literatures linking the Big Five personality traits with job performance and indicate there are trait interactions and conclude the capability to predict that employee behavior could be improved by considering the interaction among the traits. van der Linden et al. (2010) performed a meta-analysis on the inter-correlations among the Big Five personality factors (OCEAN) to test for the existence of a General Factor of Personality (GFP). Their study indicated that the GFP has a substantive component, as it is related to supervisor-rated job performance.

Borman and Motowidlo (1993) indicated that job performance included task performance and contextual performance. They tested the merit of the distinction made between task performance and contextual performance. Task performance is defined as the employee's performance on the company's core tasks and skills. Contextual performance is defined as the employee's performance on the company's non-core tasks, including providing assistance to his/her colleagues. Van Scotter (2000) studied the relationships between task performance and contextual performance with turnover, job satisfaction and affective commitment, and concluded that task performance and contextual performance predicted turnover and job satisfaction. Bing et al. (2011) studied the relationship between political skills and job performances. They found that political skill is a valid predictor of both task and contextual performance ratings. Beck et al. (2009) indicated job performance is a multidimensional concept that encompasses both task-related and contextual performance factors that include the importance of social skills as a predictor of job performance. Springer (2011) reviewed Campbell's (1990) research in industrial and organizational psychology and developed some broad items of job performance that could be applicable across various jobs. These items include eight general factors of job performance:

(1) job-specific proficiency;

(2) non-job-specific task proficiency;

(3) written and oral communication;

(4) demonstrating effort;

(5) maintaining personal discipline;

(6) maintaining peer and team performance;

(7) supervision/leadership; and

(8) management/administration.

Sisco and Reilly (2007) performed a study to test the effectiveness of using a biographical inventory as an alternative to a traditional personality inventory in measuring the FFM of personality. All participants completed the newly developed 
Biodata Inventory and the NEO-Five Factor Inventory. They found the relationship of the Conscientiousness biodata scores to grade point average and task completion performance was statistically significant. Kappe and van der Flier (2010) used multiple and specific academic performance criteria (i.e. classroom lectures, skills training, team projects, on-the-job training and a written thesis) to examine the predictive validity of the Big Five personality traits on 135 students in The Netherlands. They also found that Conscientiousness is highly correlated to performance in higher education, regardless of which performance criterion was used, and that Neuroticism is positively related to performance when the assessment conditions are less stressful. Barrick et al. (1991) examined the relationship of the Big Five personality dimensions to three job performance criteria and found conscientiousness has consistent relations with all job performance criteria for all responding occupational groups. Barrick et al. (1993) assessed the relationship of conscientiousness to job performance by linear structural equation modeling showed that salesman high in conscientiousness are more likely to have higher job performance:

H1. Conscientiousness personality trait has positive correlation with job performance.

H1.1. Conscientiousness trait has positive correlation with task performance.

H1.2. Conscientiousness trait has positive correlation with contextual performance. Yang and Hwang (2014) investigated the relationship between personality traits, job performance and job satisfaction in the financial, securities and insurance industries in Taiwan. They found extraversion is the only personality trait that shows a significant influence over job satisfaction. Meanwhile, Hurtz and Donovan (2000) showed that conscientiousness is positively relative to job performance in a meta-analysis. Thus, it is hypothesized that extraversion is positively influence job performance:

H2. Extraversion personality trait has positive correlation with job performance.

H2.1. Extraversion trait has positive correlation with task performance.

H2.2. Extraversion trait has positive correlation with contextual performance.

Judge and Erez (2007) investigates employees' emotional stability and extraversion personal traits on their job performance at a regional health and fitness center, and they found both of the abovementioned personal traits useful to predict employees' job performance. Simon (2013) studies the team personality and its impacts on team performance by meta-analysis technique, and she found that the operationalizations of team emotional stability can significantly predict team performance:

H3. Emotional stability personality trait has positive correlation with job performance.

H3.1. Emotional stability trait has positive correlation with task performance.

H3.2. Emotional stability trait has positive correlation with contextual performance.

Witt et al. (2002) studied the relationship between conscientiousness and job performance would be stronger for persons high in agreeableness. They also find workers with high conscientiousness and low in agreeableness get lower ratings of job 
MABR

1,3

performance than workers with high agreeableness. Yang and Hwang (2014) conducted surveys on Chinese employers to find out the relationship between the employees' five major personality traits and their job performance. They found all five personality traits significantly influence job performance, with agreeableness showing the greatest effect:

H4. Agreeableness personality trait has positive correlation with job performance.

H4.1. Agreeableness trait has positive correlation with task performance.

H4.1. Agreeableness trait has positive correlation with contextual performance.

Bing and Lounsbury (2000) studied job performance and openness among residents in the southeast employed in US-based Japanese manufacturing companies by a step-wise hierarchical regression technique. They found that openness predicted the job performance for these employees. O'Connor and Paunonen (2007) reviewed the relations between the Big Five personality dimensions and post-secondary academic achievement, and found Conscientiousness, in particular, to be most strongly and consistently associated with academic success. In addition, Openness to Experience was sometimes positively associated with scholastic achievement, whereas Extraversion was sometimes negatively related to the same criterion, although the empirical evidence regarding these latter two dimensions was somewhat mixed:

H5. Openness personality trait has positive correlation with job performance.

H5.1. Openness trait has positive correlation with task performance.

H5.2. Openness trait has positive correlation with contextual performance.

\section{Research methodology and research structure}

Research structure

Description statistics and regression analysis techniques are used to analyze the survey results. The regression analysis can be performed to look into the relationship between the job performance and five domains in the FFM. NEO Five-Factor Inventory (NEO-FFI-3) questions are translated into Chinese and are used to design the questionnaire. NEO-FFI-3 is composed of five domains, and each of the domains is represented by six specific scales (Table I). The questionnaire included 60 questions that assessed the five domains and 30 facet scales in the FFM. Three regression models are then tested (Figure 1):

(1) relationship of the five domains with the overall job performance;

(2) relationship of the five domains with the task performance; and

(3) relationship of the five domains with the contextual performance.

\section{Sampling}

Globally, there are around 40,000 freight forwarding companies that employed 8 million staffs in 150 countries (Elite, 2015; Chi, 2005). There are 830 freight forwarding companies that employed 10,681 professionals in Taiwan in 2013 (Maritime and Port Bureau of the MoTC, 2015). Anonymous questionnaires were distributed to 1,280 employees in according to the top 100 ocean freight forwarding members in Taipei in the 


\begin{tabular}{|c|c|c|c|}
\hline Five domains (OCEAN) & \multicolumn{2}{|l|}{ Thirty facet scales } & Application of \\
\hline \multirow[t]{3}{*}{ Openness (O): Openness to experience } & 1. Fantasy & 2. Aesthetics & traits model \\
\hline & 3. Feelings & 4. Actions & \\
\hline & 5. Ideas & 6. Values & \\
\hline \multirow[t]{3}{*}{ Conscientiousness (C) } & 7. Competence & 8. Order & \\
\hline & 9. Dutifulness & 10. Achievement striving & 23 \\
\hline & 11. Self-discipline & 12. Deliberation & \\
\hline \multirow{3}{*}{ Extraversion (E) } & 13. Warmth & 14. Gregariousness & \\
\hline & 15. Assertiveness & 16. Activity & \\
\hline & 17. Excitement-seeking & 18. Positive emotions & \\
\hline \multirow{3}{*}{ Agreeableness (A) } & 19. Trust & 20. Straightforwardness & \\
\hline & 21. Altruism & 22. Compliance & \\
\hline & 23. Modesty & 24. Tender-mindedness & \\
\hline \multirow[t]{2}{*}{ Neuroticism (N): Emotional stability } & 25. Anxiety & 26. Angry hostility & \\
\hline & $\begin{array}{l}\text { 27. Depression } \\
\text { 29 Imn1lsiveness }\end{array}$ & 28. Self-consciousness & Table I. \\
\hline \multirow{2}{*}{\multicolumn{3}{|c|}{ Source: McCrae and Costa (2004) and McCrae and Costa (2009) }} & Facet scales in the \\
\hline & & & \\
\hline
\end{tabular}

\begin{tabular}{|c|c|c|}
\hline Personality Constructs & Job Per & Demographic data \\
\hline Five Domains) & (1) Task & (1) Age \\
\hline $\begin{array}{l}\text { (1) Openness } \\
\text { (2) Conscientiousness } \\
\text { (3) Extraversion } \\
\text { (4) Agreeableness } \\
\text { (5) Neuroticism }\end{array}$ & $\begin{array}{l}\text { Performance } \\
\text { (2) Contextual } \\
\text { Performance }\end{array}$ & $\begin{array}{l}\text { (2) Marriage } \\
\text { (3) Gender } \\
\text { (4) Seniority } \\
\text { (5) Education } \\
\text { (6) Job position }\end{array}$ \\
\hline
\end{tabular}

Figure 1. Research structure

early 2013, and 168 copies of them are returned in 2013. Of the 146 returned questionnaires, two are uncompleted. The response rate is as high as 11.41 per cent (Table II), and the demographic data of the respondents are shown in Table III. As freight forwarders in Taiwan are overburdened to answer too many academic surveys, it is highly likely they would not respond to our surveys unless we have their oral agreement first. Thus, the research team members have called the reception department of these leading forwarders to find the appropriate staffs who have expressed that they are willing to fill in and return our questionnaire and to know the number of employees of the companies. For forwarder of larger scale, more copies of questionnaires are posted to its sales department. As the questionnaire is of anonymous type, it is impossible for

\begin{tabular}{lccc}
\hline Response and non-response & No. of surveyees & Valid respondents & Valid response rate \\
\hline Response & 1,280 & 146 & $11.41 \%$
\end{tabular}

Source: This research

Table II. The response rate 


\section{MABR}

1,3

Demographic variables

Gender

Male

Female

238

Age

Under 20

21-30

31-40

41-50

Over 51

Education

High School

College

Graduate School

Marriage

Married

Single

Seniority

Under 2

2-5

Over 5

Job scope

Internal OP

Table III.

Demographic data of the respondents

External sales

Source: This research
No.

$(\%)$

49.3

74

50.7

$\begin{array}{rr}4 & 2.7 \\ 50 & 28.7\end{array}$

$46 \quad 34.2$

$38-26.0$

$12 \quad 8.2$

20

13.7

108

74.0

12.3

52.1

47.9

70

15.1

23.3

61.6

92

63.0

$54-37.0$

the authors to know the exact background of the respondents. In a multiple regression model, maintaining power at 80 requires a minimum sample of 50 and preferably 100 observations for most research situations (Hair et al., 2006). Thus, the number of our respondents is appropriately to carry out the regression analysis between personality constructs and job performance constructs.

\section{Research findings}

There are four subsections in the research findings section:

(1) description on the sampling, response rate and respondents' demographic data;

(2) internal consistency reliability (Cronbach's alpha reliability) is tested, and it is used to judge the consistency of results across items on the same test of the responses of the personality traits and job performance of the employees in the ocean freight forwarding industry;

(3) regression analysis technique is used for modeling and analyzing the relationship between a job performance variable and the five domains of the FFM; and 
(4) analysis of variance (ANOVA) on the respondents' demographic data and their job performance.

Internal consistency of the questionnaire on the personal traits constructs

Overall, Cronbach's alpha measure of reliability for the FFM personality traits questionnaire is 0.683 . To increase all alpha values of the five domains to over 0.7 , some questions were deleted from the questionnaire in the Openness domain. Question items $3,8,33,38$ and 58 were deleted, and the internal consistency of the Openness domain is increased to 0.704 . One of the authors has interviewed the respondents after the survey, and respondents have complained that some questions in the openness domain are very difficult to reply. Thus, these five questions in the openness domain are removed from the FFM model (Table IV).

\section{Validity of the survey}

The FFM questionnaire is designed according to the NEO Inventories, a psychological assessment instrument distributed by the American psychological literatures publisher, PAR Inc. This personality assessment instrument has been tested and heavily used in the Western world, but it is rarely used by most of Asian academicians. The questionnaire is translated into Chinese by one of the authors and is then reviewed by a transportation psychologist in Taiwan. Thus, the content validity of the questionnaire is supported.

\section{Internal consistency of the job performance constructs}

Job performance was evaluated using the following two measures: task performance and contextual performance. First, eight items were used to measure the task performance. Second, 16 items were used to measure the contextual performance. Subjective perceptual measures of employees' job performance were adopted by Yu (1996). Internal consistency value (Cronbach's alpha) of the job performance questionnaire is shown in the following Table $\mathrm{V}$.

The overall internal consistency value for the job performance construct is 0.973 , which is larger than the threshold value of Cronbach's alpha 0.7.

\section{Validity of the job performance}

The measurement items of the job performance constructs are initially proposed by Barrick and Mount (1991) to investigate the relation of the "Big Five" personality dimensions to three job performance criteria (job proficiency, training proficiency and personnel data), and are being used by many academicians to evaluate the staffs' performance in the service industry since then. Thus, these measurement items of the construct have the content validity.

Descriptive statistics on the personality traits construct and job performances construct Questionnaires are designed according to the five-point Likert scale, each number represent different meaning as follows: 1 , strongly disagree; 2 , disagree; 3 , neutral; 4 , agree; and 5, strongly agree.

Authors have made conversion on the reverse questions when keying the respondents' replies so that the replies can indicate whether there is a positive correlation between personality trait and job performance. Items (20), (4), (5), (55) and (35) were perceived to be the top five important questions. 
MABR

1,3

Extraversion (E):

Cronbach's $\alpha$ value 0.78

\section{Table IV.}

Internal consistency of the personality traits construct $\alpha$ value 0.728
Corrected

item-total Cronbach' $\alpha$ if correlation item deleted

Openness (O): Cronbach's

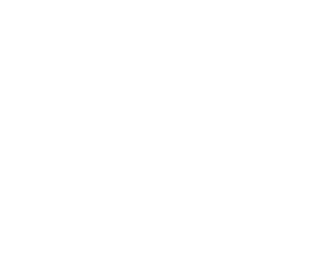

Question

$-0.189 \quad 0.367$ daydreaming $(\mathrm{R})$

8 I believe that it's better to stick to $\quad-0.068 \quad 0.313$ your own principles than to be openminded. (R)

13 I am intrigued by the patterns I find $\quad 0.267 \quad 0.161$ in art and nature

18 I believe letting students hear $\quad 0.169 \quad 0.206$ controversial speakers can only confuse and mislead them. (R)

23 Poetry has little or no effect on me. $0.161 \quad 0.214$ (R)

28 I often try new and foreign foods $\quad 0.056 \quad 0.260$

33 I seldom notice the moods or feelings $\quad 0.143 \quad 0.224$ that different environments produce. (R)

38 I believe we should look to our $\quad 0.082 \quad 0.250$ religious authorities for decisions on moral issues

43 Sometimes when I am reading poetry $\quad 0.309 \quad 0.156$ or looking at a work of art, I feel a chill or wave of excitement

48 I have little interest in speculation on $\quad 0.297 \quad 0.153$ the nature of the universe or the human condition. (R)

53 I have a lot of intellectual curiosity $\quad 0.063 \quad 0.258$

58 I often enjoy playing with theories or $\quad-0.140 \quad 0.354$ abstract ideas

2 I like to have a lot of people around $\quad 0.605 \quad 0.744$ me

7 I laugh easily $\quad 0.460 \quad 0.761$

12 I have felt overpowering joy $\quad-0.442 \quad 0.854$

17 I really enjoy talking to people $\quad 0.711 \quad 0.733$

22 I like to be where the action is $\quad 0.383 \quad 0.769$

27 I usually prefer to do things alone. (R) $\quad 0.274 \quad 0.778$

32 I often feel as if I'm bursting with $\quad 0.689 \quad 0.739$ energy

$37 \quad$ I am a cheerful, high spirited person $\quad 0.759 \quad 0.73$

42 I am not a cheerful optimist. (R) $\quad 0.48 \quad 0.758$

47 My life is fast-paced $\quad 0.289 \quad 0.777$

52 I am a active person $\quad 0.685 \quad 0.739$

57 I would rather go my own way than $\quad 0.484 \quad 0.758$ be a leader of others. $(\mathrm{R})$ 


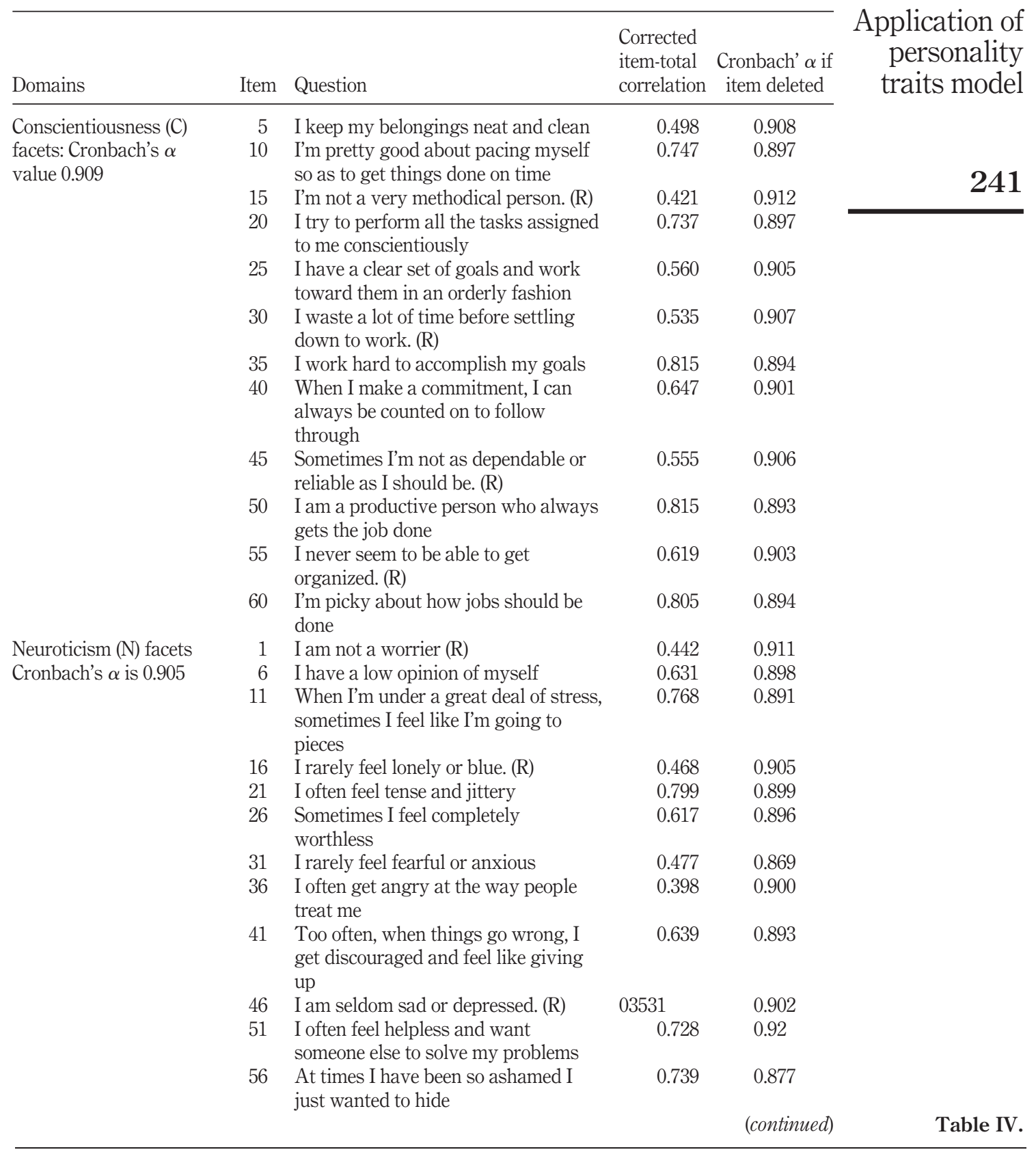




\section{MABR}

1,3

\begin{tabular}{|c|c|c|c|c|}
\hline Domains & Item & Question & $\begin{array}{l}\text { Corrected } \\
\text { item-total } \\
\text { correlation }\end{array}$ & $\begin{array}{l}\text { Cronbach' } \alpha \text { if } \\
\text { item deleted }\end{array}$ \\
\hline \multirow{12}{*}{$\begin{array}{l}\text { Agreeableness facet (A): } \\
\text { Cronbach's } \alpha \text { value } \\
0.7637\end{array}$} & 4 & $\begin{array}{l}\text { I try to be courteous to everyone I } \\
\text { meet }\end{array}$ & 0.718 & 0.708 \\
\hline & 9 & $\begin{array}{l}\text { I often get into arguments with my } \\
\text { family and co-workers. (R) }\end{array}$ & 0.598 & 0.726 \\
\hline & 14 & $\begin{array}{l}\text { Some people think I'm selfish and } \\
\text { egotistical. (R) }\end{array}$ & 0.657 & 0.717 \\
\hline & 19 & $\begin{array}{l}\text { I would rather cooperate with others } \\
\text { than compete with them }\end{array}$ & 0.527 & 0.731 \\
\hline & 24 & $\begin{array}{l}\text { I believe to be cynical and skeptical of } \\
\text { others' intentions. (R) }\end{array}$ & 0.591 & 0.722 \\
\hline & 29 & $\begin{array}{l}\text { I believe that most people will take } \\
\text { advantage of you if you let them. (R) }\end{array}$ & 0.368 & 0.75 \\
\hline & 34 & Most people I know like me & 0.518 & 0.735 \\
\hline & 39 & $\begin{array}{l}\text { Some people think of me as cold and } \\
\text { calculating. (R) }\end{array}$ & 0.57 & 0.728 \\
\hline & 44 & I'm hard headed and stubborn. (R) & -0.528 & 0.835 \\
\hline & 49 & $\begin{array}{l}\text { I generally try to be thoughtful and } \\
\text { considerate }\end{array}$ & 0.558 & 0.73 \\
\hline & 54 & $\begin{array}{l}\text { If I don't like people, I let them know } \\
\text { it. (R) }\end{array}$ & 0.051 & 0.785 \\
\hline & 59 & $\begin{array}{l}\text { If necessary, I am willing to } \\
\text { manipulate people to get what I want. }\end{array}$ & 0.385 & 0.749 \\
\hline
\end{tabular}
$(\mathrm{R})$

Table IV.

Source: Adapted from NEO Five-Factor Inventory (NEO-FFI-3) by this research

Four of the top five important items are in the "Conscientiousness (C) Facets", and their average score is near 4.0, which indicates most staffs of the ocean freight forwarding industry perceived conscientiousness as the most key successful factor if they want to prevail in the competitive freight forwarding market. Item 4 of the Agreeableness Facet (A) was ranked as the second most important personality trait with an average score of 4.0274 which implies courteousness is a necessity to solicit the shippers using forwarders' freight services (Table VI). Thus, sales team members of the forwarding industry do always wear suits to show their respect to their potential customers before they have a chance to introduce their freight services. On the other hand, the five lowest score items are all in reverse questions, and the respondents mostly do not think that they have these five negative emotions.

Regression analysis on the personality trait and job performance

Multiple regression analysis technique is used to look into the relationship between the five personality traits and each of the following job performance constructs:

- task performance construct;

- contextual performance construct; and

- overall job performance construct. 


\begin{tabular}{|c|c|c|c|c|c|}
\hline $\begin{array}{l}\text { Job performance } \\
\text { facets }\end{array}$ & Item & $\begin{array}{l}\text { Questions/Measurement } \\
\text { constructs }\end{array}$ & $\begin{array}{l}\text { Corrected item-total } \\
\text { correlation }\end{array}$ & $\begin{array}{l}\text { Cronbach's } \alpha \\
\text { value if item } \\
\text { deleted }\end{array}$ & $\begin{array}{l}\text { Application of } \\
\text { personality } \\
\text { traits model }\end{array}$ \\
\hline $\begin{array}{l}\text { (1) Contextual } \\
\text { performance }\end{array}$ & 9 & $\begin{array}{l}\text { I always cooperate with my } \\
\text { colleagues of the same team }\end{array}$ & 0.839 & 0.959 & \\
\hline \multirow[t]{13}{*}{$\begin{array}{l}\text { Cronbach's } \alpha \text { value is } \\
0.963\end{array}$} & 10 & $\begin{array}{l}\text { I frequently show my } \\
\text { patience during my }\end{array}$ & 0.681 & 0.962 & 243 \\
\hline & 11 & $\begin{array}{l}\text { working time } \\
\text { I frequently shoulder extra } \\
\text { works for my company and } \\
\text { colleagues }\end{array}$ & 0.697 & 0.962 & \\
\hline & 12 & $\begin{array}{l}\text { I used to follow operation } \\
\text { procedure and work } \\
\text { guidelines, and avoid } \\
\text { assuming my colleagues' } \\
\text { work assignment }\end{array}$ & 0.789 & 0.960 & \\
\hline & 13 & $\begin{array}{l}\text { I wish my company can } \\
\text { arrange me to handle a } \\
\text { challenging mission }\end{array}$ & 0.590 & 0.964 & \\
\hline & 14 & $\begin{array}{l}\text { I am always willing to help } \\
\text { my colleagues to complete } \\
\text { a mission which has no } \\
\text { relationship with me }\end{array}$ & 0.776 & 0.961 & \\
\hline & 15 & $\begin{array}{l}\text { I pay attentions to } \\
\text { important events to avoid } \\
\text { unexpected incidences }\end{array}$ & 0.828 & 0.960 & \\
\hline & 16 & $\begin{array}{l}\text { I fully support my } \\
\text { superiors' decisions }\end{array}$ & 0.779 & 0.961 & \\
\hline & 17 & $\begin{array}{l}\text { I have considered job ethics } \\
\text { in my work }\end{array}$ & 0.812 & 0.960 & \\
\hline & 18 & $\begin{array}{l}\text { I have encouraged and } \\
\text { supported my colleagues } \\
\text { when they encountered } \\
\text { challenges }\end{array}$ & 0.814 & 0.960 & \\
\hline & 19 & $\begin{array}{l}\text { I have voluntarily solved } \\
\text { problems in my company }\end{array}$ & 0.803 & 0.960 & \\
\hline & 20 & $\begin{array}{l}\text { I do control myself and } \\
\text { obey the work codes in my } \\
\text { company }\end{array}$ & 0.833 & 0.960 & \\
\hline & 21 & $\begin{array}{l}\text { I am willing to handle a } \\
\text { difficult assignment from } \\
\text { my company }\end{array}$ & 0.875 & 0.960 & \\
\hline & 22 & $\begin{array}{l}\text { I do shoulder extra work, } \\
\text { and am willing to help my } \\
\text { colleagues and my team to } \\
\text { improve their performance }\end{array}$ & 0.812 & (continued) & $\begin{array}{r}\text { Table V. } \\
\text { Internal consistency } \\
\text { of the job } \\
\text { performance } \\
\text { constructs }\end{array}$ \\
\hline
\end{tabular}


MABR

1,3

\begin{tabular}{|c|c|c|c|c|}
\hline $\begin{array}{l}\text { Job performance } \\
\text { facets }\end{array}$ & Item & $\begin{array}{l}\text { Questions/Measurement } \\
\text { constructs }\end{array}$ & $\begin{array}{l}\text { Corrected item-total } \\
\text { correlation }\end{array}$ & $\begin{array}{l}\text { Cronbach's o } \\
\text { value if item } \\
\text { deleted }\end{array}$ \\
\hline & 23 & $\begin{array}{l}\text { In general, I am willing to } \\
\text { help my colleagues and } \\
\text { tried to put myself in my } \\
\text { company's shoes to } \\
\text { consider the company's } \\
\text { situation }\end{array}$ & 0.789 & 0.960 \\
\hline \multirow[t]{8}{*}{$\begin{array}{l}\text { (2) Task performance } \\
\text { (Cronbach's } \alpha 0.941 \text { ) }\end{array}$} & 1 & $\begin{array}{l}\text { I must complete work } \\
\text { assignment according to } \\
\text { standard operation } \\
\text { procedure }\end{array}$ & 0.719 & 0.938 \\
\hline & 2 & $\begin{array}{l}\text { I am familiar with the SOP } \\
\text { of my work }\end{array}$ & 0.795 & 0.932 \\
\hline & 3 & $\begin{array}{l}\text { I often well plan and } \\
\text { arrange my work progress }\end{array}$ & 0.795 & 0.932 \\
\hline & 4 & $\begin{array}{l}\text { I have paid attention to the } \\
\text { sanitary and safety issues } \\
\text { during my work }\end{array}$ & 0.801 & 0.932 \\
\hline & 5 & $\begin{array}{l}\text { I always keep my work } \\
\text { shop floor clean and tidy }\end{array}$ & 0.795 & 0.932 \\
\hline & 6 & $\begin{array}{l}\text { I used to have my work } \\
\text { tools and stationery in } \\
\text { fixed places after I used } \\
\text { them }\end{array}$ & 0.821 & 0.930 \\
\hline & 7 & $\begin{array}{l}\text { My average working } \\
\text { efficiency is high }\end{array}$ & 0.783 & 0.932 \\
\hline & 8 & $\begin{array}{l}\text { In general, I can complete } \\
\text { my work according to my } \\
\text { company's request }\end{array}$ & 0.802 & 0.930 \\
\hline
\end{tabular}

Table V.

Source: Compiled from Borman and Motowidlo (1997) and NEO Five-Factor Inventory (NEO-FFI-3) by this research

The five personality traits will be the independent variables, while each of the three performance constructs is the dependent variable. R-square (the coefficient of determination) is used to tell the prediction ability of our proposed regression model on the basis of other related information. DW statistics is used to test for serial correlation in the residuals containing lagged endogenous variables. The variance inflation factor and tolerance are both used to measure the degree of multi-collinearity of the $i^{\text {th }}$ independent variable with the other independent variables in a regression model. The relationships of the job performance construct and FFM personality traits are shown in the following three tables (Tables VII-IX).

\section{Analysis on the demographic data and job performance}

Different demographic characteristics of the respondents might have various impacts on their job performance. Thus, ANOVA between demographic data and job performance is made in the following table. 


\begin{tabular}{|c|c|c|c|c|c|}
\hline Items & Question description & Average score & $\mathrm{SD}$ & Rank & $\begin{array}{l}\text { tion of } \\
\text { nality }\end{array}$ \\
\hline 20 & $\begin{array}{l}\text { I try to perform all the tasks assigned to me } \\
\text { conscientiously }\end{array}$ & 4.0822 & 0.89370 & 1 & traits model \\
\hline 4 & I try to be courteous to everyone I meet & 4.0274 & 0.91245 & 2 & \\
\hline 5 & I keep my belongings neat and clean & 3.9863 & 0.87390 & 3 & \\
\hline 55 & I am able to get organized & 3.9175 & 0.95348 & 4 & 245 \\
\hline 35 & I work hard to accomplish my goals & 3.9041 & 0.78465 & 5 & \\
\hline 15 & I'm a very methodical person & 3.9041 & 0.95981 & 6 & \\
\hline 24 & $\begin{array}{l}\text { I believe not to be cynical and skeptical of } \\
\text { others' intentions }\end{array}$ & 3.8493 & 1.00928 & 7 & \\
\hline 19 & $\begin{array}{l}\text { I would rather cooperate with others than } \\
\text { compete with them }\end{array}$ & 3.8493 & 0.95265 & 8 & \\
\hline 60 & I'm picky about how jobs should be done & 3.8356 & 0.89774 & 9 & \\
\hline 50 & $\begin{array}{l}\text { I am a productive person who always gets the } \\
\text { job done }\end{array}$ & 3.8219 & 0.90281 & 10 & \\
\hline 17 & I really enjoy talking to people & 3.7534 & 0.90935 & 11 & \\
\hline 9 & $\begin{array}{l}\text { I rarely get into arguments with my family and } \\
\text { co-workers }\end{array}$ & 3.7397 & 0.81696 & 12 & \\
\hline 45 & $\begin{array}{l}\text { Most of times, I'm as dependable or reliable as I } \\
\text { should be }\end{array}$ & 3.7123 & 0.96436 & 13 & \\
\hline 2 & I like to have a lot of people around me & 3.6986 & 0.99561 & 14 & \\
\hline 14 & Some people think I'm not selfish and egotistical & 3.6712 & 0.89837 & 15 & \\
\hline 40 & $\begin{array}{l}\text { When I make a commitment, I can always be } \\
\text { counted on to follow through }\end{array}$ & 3.6575 & 0.85341 & 16 & \\
\hline 10 & $\begin{array}{l}\text { I'm pretty good about pacing myself so as to get } \\
\text { things done on time }\end{array}$ & 3.6575 & 0.86935 & 17 & \\
\hline 49 & I generally try to be thoughtful and considerate & 3.6164 & 0.84377 & 18 & \\
\hline 39 & $\begin{array}{l}\text { Most people think of me as warm and not } \\
\text { calculating }\end{array}$ & 3.6027 & 0.87781 & 19 & \\
\hline 7 & I laugh easily & 3.6027 & 0.99638 & 20 & \\
\hline 53 & I have a lot of intellectual curiosity & 3.5890 & 0.87932 & 21 & \\
\hline 13 & $\begin{array}{l}\text { I am intrigued by the patterns I find in art and } \\
\text { nature }\end{array}$ & 3.5890 & 0.96947 & 22 & \\
\hline 25 & $\begin{array}{l}\text { I have a clear set of goals and work toward them } \\
\text { in an orderly fashion }\end{array}$ & 3.5753 & 0.86471 & 23 & \\
\hline 52 & I am an active person & 3.5753 & 0.83196 & 24 & \\
\hline 34 & Most people I know like me & 3.5342 & 0.78319 & 25 & \\
\hline 57 & $\begin{array}{l}\text { I would rather be a leader of others than go my } \\
\text { own way }\end{array}$ & 3.5068 & 0.89943 & 26 & \\
\hline 37 & I am a cheerful, high spirited person & 3.4795 & 0.86778 & 27 & \\
\hline 30 & $\begin{array}{l}\text { I don't waste a lot of time before settling down to } \\
\text { work }\end{array}$ & 3.4658 & 0.92919 & 28 & \\
\hline 32 & I often feel as if I'm bursting with energy & 3.3973 & 0.82898 & 29 & \\
\hline 18 & $\begin{array}{l}\text { I believe letting students hear controversial } \\
\text { speakers will not confuse and will not mislead } \\
\text { them }\end{array}$ & 3.3973 & 1.03735 & 30 & $\begin{array}{r}\text { Table VI. } \\
\text { Descriptive statistics }\end{array}$ \\
\hline 42 & I am a cheerful optimist & 3.3699 & 0.99313 & 31 & on the personality \\
\hline 38 & $\begin{array}{l}\text { I believe we should look to our religious } \\
\text { authorities for decisions on moral issues }\end{array}$ & 3.3151 & 0.95564 & 32 & $\begin{array}{r}\text { trait and } \\
\text { performance } \\
\text { constructs }\end{array}$ \\
\hline
\end{tabular}




\section{MABR \\ 1,3}

\begin{tabular}{llccc}
\hline Items & Question description & Average score & SD & Rank \\
\hline 28 & I often try new and foreign foods & 3.3151 & 0.81440 & 33 \\
59 & $\begin{array}{l}\text { Even if necessary, I am not willing to manipulate } \\
\text { people to get what I want }\end{array}$ & 3.2055 & 1.05355 & 34 \\
33 & $\begin{array}{l}\text { I frequently notice the moods or feelings that } \\
\text { different environments produce }\end{array}$ & 3.1918 & 0.89221 & 35 \\
47 & $\begin{array}{l}\text { My life is fast-paced } \\
\text { If I don't like people, I won't let them know it }\end{array}$ & 3.1918 & 0.84422 & 36 \\
54 & $\begin{array}{l}\text { I believe that most people will not take } \\
\text { advantage of you if you let them }\end{array}$ & 3.0822 & 0.9732 & 37 \\
43 & $\begin{array}{l}\text { Sometimes when I am reading poetry or looking } \\
\text { Som }\end{array}$ & 3.0548 & 0.83150 & 38
\end{tabular}

246 at a work of art, I feel a chill or wave of excitement

22 I like to be where the action is

27 I usually prefer to do things alone

48 I have strong interest in speculation on the nature of the universe or the human condition

23 Poetry has major effect on me

$46 \quad$ I am frequently sad or depressed

16 I frequently feel lonely or blue

1 I am a worrier

12 I have felt overpowering joy

$31 \quad$ I rarely feel fearful or anxious

36 I often get angry at the way people treat me

44 I'm not hard headed and not stubborn

41 Too often, when things go wrong, I get

discouraged and feel like giving up

11 When I'm under a great deal of stress, sometimes I feel like I'm going to pieces

21 I often feel tense and jittery

56 At times I have been so ashamed I just wanted to hide

$3 \quad$ I do like to waste my time daydreaming

51 I often feel helpless and want someone else to solve my problems

8 I don't believe that it's better to stick to your own principles than to be open-minded

Table VI. $\quad 6$

Descriptive statistics 58 on the personality trait and performance constructs
I have a low opinion of myself

I often enjoy playing with theories or abstract ideas

26 Sometimes I feel completely worthless
3.0274

3.0137

0.86995

0.79045

2.95890

0.90429

2.9315

2.8356

2.7945

2.7808

2.6849

2.63 .01

2.6027

2.5890

2.5068

2.4795

2.4247

2.4247

0.93287

0.78198

0.86537

1.20470

1.03918

0.85808

0.82565

0.87932

0.88386

0.9442

0.94160

0.88062

0.97904

0.86405

2.3699

0.92323

2.3014

2.1918

2.1781

1.03625

1.04539

2.0822

1.0202
57

58

40

41

42

43

44

45

46

47

48

49

50

51

52

53

54

55

56

59

60

Source: This research

ANOVA table reveals that age and marriage status have significant correlation with job performance. To be more specific, this research results imply the older the staff, the higher the job performance, and the married staff have higher job performance than the unmarried ones. This finding might be a little bit odd to the managers in the forwarding industry where young salesmen are mostly at their late twenties and early thirties. 
Correlation between personality traits and job performance

To sum up the research findings in Section 4.7, eight of the fifteen hypotheses are supported: H1, H1.1, H1.2, H2, H2.1, H2.2, H3.1 and H5.2.

In a short summary, items of the consciousness facet and extraversion facet have positive correlation with the task performance and contextual performance (and hence the overall job performance). In the regression model 3 , five personality traits in the FFM model have high correlation with the overall job performance. The coefficient of determination is as high as 0.754 which implies around 75 per cent of

\section{Model 1}

\begin{tabular}{llrrlccc}
$\begin{array}{l}\text { Independent } \\
\text { variables }\end{array}$ & $\begin{array}{l}\text { Dependent } \\
\text { variable }\end{array}$ & $\begin{array}{l}\text { Regression } \\
\text { coefficient }\end{array}$ & $t$ value & Significance & $R^{2}$ & Durbin-Watson & VIF \\
\hline Neuroticism & Task & -0.014 & -0.115 & 0.909 & 0.73 & 2.219 & 3.67 \\
Extraversion & performance & 0.233 & 2.307 & $0.024^{*}$ & & & 2.69 \\
Openness & & -0.097 & -1.045 & 0.3 & & & 2.3 \\
Agreeableness & & -0.023 & -0.246 & 0.806 & & & 2.246 \\
Consciousness & 0.752 & 6.234 & $0.000^{* *}$ & & & 3.84
\end{tabular}

Note: *Denotes significance at 0.05 , and $* *$ denotes significance at 0.01 levels

Source: This research
Application of personality traits model

Table VII.

Regression model 1 (personality traits and task performance)

Model 2

Independent

Dependent Regression

Adjusted

variables variable

coefficient $t$ value Significance

$R^{2}$

Durbin-Watson VIF

\begin{tabular}{llllllll}
\hline Neuroticism & Contextual & 0.26 & 2.122 & $0.038^{*}$ & 0.705 & 1.9645 & 3.277 \\
Extraversion & performance & 0.312 & 2.967 & $0.004^{* *}$ & & & 2.693 \\
Openness & & 0.197 & 2.025 & $0.047^{*}$ & & & 2.3 \\
Agreeableness & & 0.175 & 1.822 & 0.073 & & & 2.246 \\
Consciousness & 0.522 & 4.159 & $0.000^{* *}$ & & & 3.846
\end{tabular}

Note: *Denotes significance at 0.05 , and $* *$ denotes significance at 0.01 levels

Source: This research
Table VIII.

Regression model 2 (personality traits and contextual performance)

\begin{tabular}{llcccccc}
$\begin{array}{l}\text { Model } 3 \\
\begin{array}{l}\text { Independent } \\
\text { variables }\end{array}\end{array}$ & $\begin{array}{l}\text { Dependent } \\
\text { variable }\end{array}$ & $\begin{array}{c}\text { Regression } \\
\text { coefficient }\end{array}$ & $t$ value & Significance & $\begin{array}{c}\text { Adjusted } \\
R^{2}\end{array}$ & Durbin-Watson & VIF \\
\hline Neuroticism & Job & 0.123 & 1.098 & 0.276 & 0.754 & 2.113 & 3.679 \\
Extraversion & performance & 0.28 & 2.918 & $0.005^{*}$ & & & 2.693 \\
Openness & & 0.046 & 0.524 & 0.621 & & & 2.3 \\
Agreeableness & 0.075 & 0.861 & 0.393 & & & 2.246 \\
Consciousness & 0.662 & 5.771 & $0.000^{* *}$ & & & 3.846
\end{tabular}

Note: *Denotes significance at 0.05 , and $* *$ denotes significance at 0.01 levels

Source: This research

Table IX.

Regression model 3 (personality traits and overall job performance) 
MABR 1,3

variance of the overall job performance could be explained by the personality traits of the FFM model. Personality traits do have significant influence on the overall job performance.

In addition, items in consciousness facet have the greatest impact on the overall job performance. In regression model 3 , the coefficient of determination ( $\beta$ value) of the consciousness facet is 0.662. This finding is consistent with Barrick and Mount's (1991) research report which pinpoints consciousness is the necessity of good performance on a job. Extraversion facet is the second important facet influence on job performance. The coefficient of determination ( $\beta$ value) is 0.28 with $p$-value less than 0.05 , which implies it has significant correlation with overall job performance. Persons with high extraversion personality trait are self-confident, active, show off, pro-social activity oriented and enjoy staying with crowd. Freight forwarding business is a performance-oriented industry; sales representatives of a forwarding company have to contact with shippers frequently and require good communication and human skills to deal with their customer demands. Staffs with extraversion personality traits can easily close the relationship with shippers and thus could have better job performance when compared to their non-extraversion-oriented cohorts.

\section{Conclusion and suggestions}

Other personality traits, such as neuroticism, openness and agreeableness, have no significant correlation with overall job performance. Demographic variables such as age and marital status have significant correlation with job performance. In addition to their financial support obligation to their family, old staffs are usually senior staffs with many working experiences and personal networking; thus, they are comparatively diligent than their younger and single cohorts.

Freight forwarders in Taiwan have to recruit thousands of graduates from universities annually. These young salesmen's turnover rate is high which will result in high recruitment and orientation cost. If an appropriate personality train inventory could be used to test the job applicants before the new staffs are accepted to work for a forwarder, then the new employees' long-term retaining rate will be high.

It will be beneficial both to universities and the freight forwarding industry if the latter can help maritime and logistics universities set up a personality inventory test bank, then undergraduate students can know the fitness of their personality with their future possible jobs. It will remove inefficient learning progress for those students' personalities that are not fit with the freight forwarding industry. The freight forwarding industry can also cooperate with leading job banks to improve their databases with appropriate personality inventory survey questions. Thus, these leading job banks would not forward inappropriate job applicants to the freight forwarding industry.

\section{Implications for further research}

Respondents of this research are limited to sales representative work in the ocean freight forwarding companies in Taiwan. In terms of geographical coverage, future research could generalize the current research findings by posting questionnaires to ocean freight forwarding companies located in leading maritime nations. Future researchers could also include the operation staffs of the freight forwarding companies as their surveyees. The personalities of shipping professionals work in the operation department and sales department of a freight forwarding companies might be quite different. 


\section{References}

Aksu, A. (2008), "Chapter 10 Employee turnover: calculation of turnover rates and costs", in Tesone, D. (Ed.), Handbook of Hospitality Human Resources Management, ButterworthHeinemann, Oxford, pp. 195-222.

Ashton, M.C. (1998), "Personality and job performance: the importance of narrow traits", Journal of Organizational Behavior, Vol. 19 No. 3, pp. 289-303.

Barrick, M.R. and Mount, M.K. (1991), "The big five personality dimensions and job performance: a meta-analysis”, Personnel Psychology, Vol. 44 No. 1, pp. 1-26.

Barrick, M.R., Mount, M.K. and Strauss, J.P. (1993), "Conscientiousness and performance of sales representatives: test of the mediating effects of goal setting", Journal of Applied Psychology, Vol. 78, pp. 715-722.

Beck, J., Knutson, B., Cha, J. and Kim, S. (2009), "Developing revenue managers: a challenge for the lodging industry", Proceedings of the 2009 International Council on Hotel, Restaurant, and Institutional Education (CHRIE) Conference, USA.

Berhalter, W. (2011), "Employer'S hidden costs", available at: www.hawaiicareers.com/ retrainingcost.htm (accessed 10 March 2011).

Bing, M.N. and Lounsbury, J.W. (2000), "Openness and job performance in US-based Japanese manufacturing companies”, Journal of Business and Psychology, Vol. 14 No. 3, pp. 515-522.

Bing, M.N., Davison, H.K., Minor, I., Novicevic, M.M. and Frink, D.D. (2011), “The prediction of task and contextual performance by political skill: A meta-analysis and moderator test", Journal of Vocational Behavior, Vol. 79 No. 2.

Blickle, G., Wendel, S. and Ferris, G.R. (2010), "Political skill as moderator of personality - Job performance relationships in socioanalytic theory: test of the getting ahead motive in automobile sales", Journal of Vocational Behavior, Vol. 76 No. 2, pp. 326-335.

Blickle, G., Meurs, J.A., Zettler, I., Solga, J., Noethen, D., Kramer, J. and Ferris, G.R. (2009), "Personality, political skill, and job performance", Journal of Vocational Behavior, Vol. 72 No. 3, pp. 377-387.

Borman, W.C. and Motowidlo, S.J. (1993), "Expanding the criterion domain to include elements of contextual performance", in Schmitt, N. and Borman, W.C. (Eds), Personnel Selection in Organizations, Jossey-Bass, San Francisco, CA, pp. 71-98.

Bowler, M.C., Bowler, J.L. and Phillips, B.C. (2009), "The Big-5 \pm 2 ? The impact of cognitive complexity on the factor structure of the five-factor model", Personality and Individual Differences, Vol. 47 No. 8, pp. 979-984.

Campbell, J.P. (1990), Modeling The Performance Prediction Problem in Industrial and Organizational Psychology, Consulting Psychologists Press, Palo Alto, CA.

Chi, H.T. (2005), "Logistics industrial report", available at: ebooks.lib.ntu.edu.tw/1_file/ (accessed 27 September 2016).

Costa, P.T. and McCrae, R.R. (1992), Revised NEO Personality Inventory (NEO-PI-R) and NEO Five-Factor Inventory (NEO-FFI) Professional Manual, Psychological Assessment Resources, Odessa, FL.

Day, D.V. and Silverman, S.B. (1989), "Personality and job performance: evidence of incremental validity”, Personnel Psychology, Vol. 42 No. 1, pp. 25-36.

Dudley, N.M., Orvis, K.A., Lebiecki, J.E. and Cortina, J.M. (2006), “A meta-analytic investigation of conscientiousness in the prediction of job performance: examining the intercorrelations and the incremental validity of narrow traits", Journal of Applied Psychology, Vol. 91 No. 1, pp. 40-57.
Application of personality traits model

$-$ 
MABR

1,3

Elite (2015), “Accomplished projects”, available at: http://elitepco.a-team.com.tw/event/2015\%E5 $\%$ B9 $\%$ B4 $\%$ E5 $\% 9 \mathrm{C} \% 8 \mathrm{~B} \% \mathrm{E} 9 \% 9 \mathrm{~A} \% 9 \mathrm{~B} \% \mathrm{E} 9 \% 81 \% 8 \mathrm{~B} \% \mathrm{E} 9 \% 80 \% 81 \% \mathrm{E} 7 \% 89 \% \mathrm{~A} 9 \% \mathrm{E}$ $6 \% \mathrm{~B} 5 \% 81 \% \mathrm{E} 8 \% 81 \% \mathrm{AF} \% \mathrm{E} 5 \% 90 \% 88 \% \mathrm{E} 5 \% 8 \mathrm{D} \% 94 \% \mathrm{E} 6 \% 9 \mathrm{C} \% 83 \% \mathrm{E} 5 \% 85 \% \mathrm{~A} 8 \% \mathrm{E}$ 7\%90\%83\%E5\%B9\%B4\%E6\%9C\%83-fiata-2015/ (accessed 27 September 2016).

Filip, L., Filip, D.F. and Van Dam, K. (2001), “Assessors' use of personality traits in descriptions of assessment centre candidates: a five-factor model perspective”, Journal of Occupational and Organizational Psychology, Vol. 74 No. 5, pp. 623-636.

Furnham, A. and Fudge, C. (2008), "The five factor model of personality and sales performance", Journal of Individual Differences, Vol. 29 No. 1, pp. 11-16.

Hair, J.F., Black, W.C., Babin, B.J., Anderson, R.E. and Tatham, R.L. (2006), Multivariate Data Analysis, 6th ed., Person Education, Upper Saddle River, NJ.

Hogan, R. (1991), "Personality and personality measurement", in Dunnette, M.D. and Hough, L.M. (Eds), Handbook of Industrial and Organizational Psychology, 2nd ed., Consulting Psychologists Press, Vol. 2, Palo Alto, CA, pp. 327-396.

Hurtz, G.M. and Donovan, J.J. (2000), "Personality and job performance: the big five revisited", Journal of Applied Psychology, Vol. 85 No. 6, pp. 869-879.

Judge, T. and Erez, A. (2007), "Interaction and intersection: the constellation of emotional stability and extraversion in predicting performance”, Personnel Psychology, Vol. 60 No. 3, pp. 573-596.

Kappe, R. and van der Flier, H. (2010), "Using multiple and specific criteria to assess the predictive validity of the Big Five personality factors on academic performance", Journal of Research in Personality, Vol. 44 No. 1, pp. 142-145.

McCrae, R.R. and Costa, P.T. (2004), "A contemplated revision of the NEO Five-Factor Inventory”, Personality and Individual Differences, Vol. 36 No. 3, pp. 587-596.

McCrae, R.R. and Costa, P.T. (2009), NEO Inventory for the NEO Five Factor Inventory (NEO-FFI), Par, Lutz, FL.

Maritime and Port Bureau of the MoTC (2015), Unpublished internal data of the MPB, MoTC, Taiwan.

Muller, A. (2011), “The cost of hiring a new employee”, available at: www.investopedia.com/ financial-edge/0711/the-cost-of-hiring-a-new-employee.aspx (accessed 2 November 2016).

O'Connor, M.C. and Paunonen, S.V. (2007), "Big Five personality predictors of post-secondary academic performance", Personality and Individual Differences, Vol. 43 No. 5, pp. 971-990.

Ones, D.S., Viswesvaran, C. and Reiss, A.D. (1996), "Role of social desirability in personality testing for personnel selection: the red herring", Journal of Applied Psychology, Vol. 81 No. 6, pp. 660-679.

Parker, J.D.A., Bagby, R.M. and Summerfeldt, L.J. (1993), “Confirmatory factor analysis of the revised NEO personality inventory", Personality and Individual Differences, Vol. 15 No. 4, pp. 463-466.

Penney, L.M., David, E. and Witt, L.A. (2011), "A review of personality and performance: Identifying boundaries, contingencies, and future research directions", Human Resource Management Review, Vol. 21 No. 4, pp. 257-394.

PR Newswire (2015), Employee Exoduses Trending: Sterling Tackles Costly Staff Turnover for Private Practice Professionals: Rising employee turnover hits practice owners with sky-high replacement costs and lowered productivity. While practices struggle to retain quality staff, Sterling's practice management firm reduces turnover by making practitioners into savvy CEOs, PR Newswire, New York, NY, 7 April 2015. 
Simon, K.M. (2013), “The intelligence and team personality predicting team performance”, $P h D$ Dissertation, University of Minnesota.

Sisco, H. and Reilly, R.R. (2007), "Development and validation of a Biodata Inventory as an alternative method to measurement of the five factor model of personality", The Social Science Journal, Vol. 44 No. 2, pp. 383-389.

Springer, G.J. (2011), “A study of job motivation, satisfaction, and performance among bank employees”, Journal of Global Business, Vol. 5 No. 1, pp. 29-42.

Stone, G.J. and Ineson, E.M. (1997), "An international comparison of personality differences between hospitality and other sector managers", International Journal of Selection and Assessment, Vol. 5 No. 4, pp. 215-228.

Van Scotter, J.R. (2000), "Relationships of task performance and contextual performance with turnover, affective commitment, and affective commitment", Human Resource Management Review, Vol. 10 No. 1, pp. 79-95.

van der Linden, D., Nijenhuis, J.T. and Bakker, A.B. (2010), "The general factor of personality: a meta-analysis of big five intercorrelations and a criterion-related validity study", Journal of Research in Personality, Vol. 44 No. 3, pp. 315-327.

White,J.K. (2003), "The five -factor model personality variables and relationship variables: a study of associations", PhD Dissertation, TX Tech University.

Witt, L.A., Burke, L.A., Barrick, M.R. and Mount, M.K. (2002), "The interactive effects of conscientiousness and agreeableness on job performance", Journal of Applied Psychology, Vol. 87 No. 1, pp. 164-169.

Yang, C.L. and Hwang, M. (2014), "Personality traits and simultaneous reciprocal influences between job performance and job satisfaction”, Chinese Management Studies, Vol. 8 No. 1, pp. 26-26.

$\mathrm{Yu}$, T.C. (1996), "The influence of human side system factors on the work performance in a context of quality management", Unpublished PhD Dissertation, National Sun Yat-Sen University, ROC.

\section{Further reading}

Borman, W.C. and Motowidlo, S.J. (1997), “Task performance and contextual performance: the meaning for personnel selection research", Journal of Human Performance, Vol. 10 No. 2, pp. 99-109.

Foster, J. (2010), "What is employee turnover?", available at: www.wisegeek.com/what-isemployee-turnover.htm (accessed 10 March 2011).

Karatepe, O.M., Uludag, O., Menevis, I., Hadzimehmedagic, L. and Baddar, L. (2006), “The effects of selected individual characteristics on frontline employee performance and job satisfaction”, Tourism Management, Vol. 27 No. 4, pp. 547-560.

McCrae, R.R. and Costa, P.T. Jr. (1987), "Validation of the five-factor model of personality across instruments and observers", Journal of Personality and Social Psychology, Vol. 52 No. 1, pp. 81-90. 
MABR

1,3

252

Appendix 1

\begin{tabular}{lrrrrrrrrrrrrr}
\hline \multicolumn{11}{c}{ No. of Ocean Freight Forwarder Companies (OFFs) in Taiwan } \\
\hline $\begin{array}{l}\text { Year } \\
\begin{array}{l}\text { Number of } \\
\text { company }\end{array}\end{array}$ & 2004 & 2005 & 2006 & 2007 & 2008 & 2009 & 2010 & 2011 & 2012 & 2013 & 2014 & 2015 \\
$\begin{array}{l}\text { Number of } \\
\text { staffs }\end{array}$ & 11,167 & 8,456 & 10,380 & 7,498 & 10,480 & 11,779 & 11,331 & 11,776 & 9,470 & 10,681 & NA & NA \\
$\begin{array}{l}\text { Revenue } \\
\text { (Billion NTD) }\end{array}$ & 42.8 & 40.9 & 59.9 & 46.5 & 52.7 & 41.4 & 58.6 & 43.7 & 58.4 & 56.1 & NA & NA
\end{tabular}

Note: Revenue value is an unpublished statistics data reported by Executive Yuan

\section{Table AI.}

The OCCs' revenue, number of staffs and revenue in Taiwan
Source: The number of OFFs is collected from the Annual Report of the Ministry of Transportation and Communication between 2004 and 2014. The number of OFFs in 2015 is collected from the Maritime and Port Bureau of the MoTC. Number of employees and company revenue is found in the transportation and warehousing survey report (2004-2014) (Custom Administration, Ministry of Finance, 2004-2015)

\section{Appendix 2}

Table AII.

Average staffs turnover rate in the logistics industry in China

\begin{tabular}{lccccrc}
\hline & $\begin{array}{c}\text { Executive officers } \\
\text { level (\%) }\end{array}$ & $\begin{array}{c}\text { Directors } \\
\text { level (\%) }\end{array}$ & $\begin{array}{c}\text { Managers } \\
\text { level (\%) }\end{array}$ & $\begin{array}{c}\text { Supervisor } \\
\text { level (\%) }\end{array}$ & $\begin{array}{r}\text { Senior } \\
\text { staffs } \\
(\%)\end{array}$ & $\begin{array}{c}\text { Junior } \\
\text { staffs } \\
(\%)\end{array}$ \\
\hline Average & 3.1 & 5.0 & 8.0 & 13.5 & 10.5 & 14.5 \\
Ship owners & 0.0 & 3.5 & 6.4 & 7.7 & 6.6 & 14.2 \\
Freight forwarding & 4.2 & 3.2 & 7.0 & 7.1 & 13.7 & 14.9 \\
Logistics companies & 0.0 & 16.7 & 12.5 & 20.9 & 11.2 & 27.4
\end{tabular}

Source: www.cntrans.cn/newsShow.php?id $=651 \&$ nodeid $=88010002$

\section{Corresponding author}

Taih-Cherng Lirn can be contacted at: tedlirn@email.ntou.edu.tw

For instructions on how to order reprints of this article, please visit our website: 